\title{
Acetylcholine induces GABA release onto rod bipolar cells through heteromeric nicotinic receptors expressed in A17 amacrine cells
}

\author{
Claudio Elgueta ${ }^{1,2 *}$, Alex H. Vielma ${ }^{1}$, Adrian G. Palacios ${ }^{1}$ and Oliver Schmachtenberg ${ }^{1}$ \\ 1 Centro Interdisciplinario de Neurociencia de Valparaíso, Facultad de Ciencias, Universidad de Valparaíso, Valparaíso, Chile \\ ${ }^{2}$ Systemic and Cellular Neurophysiology, Institute of Physiology I, Albert-Ludwigs-Universität, Freiburg, Germany
}

Edited by:

Jonathan Mapelli, University of

Modena and Reggio Emilia, Italy

Reviewed by:

Evanna Gleason, Louisiana State

University, USA

Christianne E. Strang, University of

Alabama at Birmingham, USA

\section{*Correspondence:}

Claudio Elgueta, Systemic and

Cellular Neurophysiology, Institute

of Physiology I,

Albert-Ludwigs-Universität,

Hermann-Herder Strasse 7, D-79104,

Freiburg, Germany

e-mail: claudio.elgueta@

physiologie.uni-freiburg.de
Acetylcholine (ACh) is a major retinal neurotransmitter that modulates visual processing through a large repertoire of cholinergic receptors expressed on different retinal cell types. ACh is released from starburst amacrine cells (SACs) under scotopic conditions, but its effects on cells of the rod pathway have not been investigated. Using whole-cell patch clamp recordings in slices of rat retina, we found that ACh application triggers GABA release onto rod bipolar (RB) cells. GABA was released from A17 amacrine cells and activated postsynaptic $G_{A B A}$ and $G A B A_{C}$ receptors in $R B$ cells. The sensitivity of ACh-induced currents to nicotinic ACh receptor (nAChR) antagonists (TMPH mecamylamine $>$ erysodine $>$ Dh $\beta E>M L A$ ) together with the differential potency of specific agonists to mimic ACh responses (cytisine $>>$ RJR2403 choline), suggest that A17 cells express heteromeric nAChRs containing the $\beta_{4}$ subunit. Activation of nAChRs induced GABA release after $\mathrm{Ca}^{2+}$ accumulation in $\mathrm{A} 17$ cell dendrites and varicosities mediated by L-type voltage-gated calcium channels (VGCCs) and intracellular $\mathrm{Ca}^{2+}$ stores. Inhibition of acetylcholinesterase depolarized A17 cells and increased spontaneous inhibitory postsynaptic currents in RB cells, indicating that endogenous ACh enhances GABAergic inhibition of RB cells. Moreover, injection of neostigmine or cytisine reduced the b-wave of the scotopic flash electroretinogram (ERG), suggesting that cholinergic modulation of GABA release controls RB cell activity in vivo. These results describe a novel regulatory mechanism of RB cell inhibition and complement our understanding of the neuromodulatory control of retinal signal processing.

Keywords: acetylcholine, A17 amacrine cell, GABA, GABA receptors, nicotinic receptor, retina, rod bipolar cell, rod pathway

\section{INTRODUCTION}

Nicotinic acetylcholine receptors are widely distributed throughout the central nervous system and play essential roles in learning, cognition and addiction (Dani and Bertrand, 2007). Central nAChRs are pentameric cationic channels assembled as homomers of $\alpha_{7}-\alpha_{9}$ subunits or by combinations of $\alpha_{2}-\alpha_{6}$ and $\beta_{2}-\beta_{4}$ subunits (Millar and Gotti, 2009). This heterogeneity endows nAChRs with different physiological and pharmacological properties and therefore diverse functional roles in neuronal networks (Mansvelder et al., 2006; Dani and Bertrand, 2007; Albuquerque et al., 2009).

In the mammalian retina, ACh is synthesized and released from starburst amacrine cells (SACs) that form narrowly defined cholinergic plexuses in the inner plexiform layer (IPL) (Voigt, 1986). Release of ACh may activate different classes of cholinergic receptors present in bipolar, amacrine and ganglion cells (AC and GCs) (Keyser et al., 2000; Dmitrieva et al., 2001, 2003,

Abbreviations: AC, amacrine cell; ACh, acetylcholine; CP-AMPAR, calcium permeable AMPA receptor; CICR, calcium induced calcium release; GC, ganglion cell; IPL, inner plexiform layer; $\mathrm{nAChR}$, nicotinic acetylcholine receptor; RB, rod bipolar.
2007; Moretti et al., 2004; Marritt et al., 2005; Strang et al., 2010). Indeed, functional nAChRs are expressed in GCs that stratify close to SAC dendrites (Kittila and Massey, 1997; Fried et al., 2005; Reed et al., 2005; Strang et al., 2007; Briggman et al., 2011) as well as in cells whose processes are located far from these cholinergic bands (Masland and Ames, 1976; Ariel and Daw, 1982; Schmidt et al., 1987; Strang et al., 2003, 2005). Activation of nAChRs also modulates the ON bipolar cell-dependent b-wave of the electroretinogram (ERG) (Jurklies et al., 1996; Varghese et al., 2011; Moyano et al., 2013), suggesting that ACh may influence signal transmission at stages preceding GC activation, but its specific targets and mechanisms of action remain largely unknown.

ACh release occurs under a broad range of illuminations (Masland and Livingstone, 1976; Massey and Neal, 1978, 1979b; O'Malley and Masland, 1993), including scotopic conditions when luminous signals detected by rods are mainly processed by the classic rod pathway. The first steps in this circuit involve the sequential activation of two dedicated cell types, RB and AII-ACs. The latter form chemical and electric synapses with cone bipolar cells to convey rod signals to GCs (Bloomfield and Dacheux, 
2001; Wässle, 2004). Glutamate release from RB to AII cells remains tightly controlled by numerous reciprocal GABAergic synapses between A17 AC and RB cell axons (Hartveit, 1999; Singer and Diamond, 2003; Chávez et al., 2006), providing stability and enhanced temporal resolution at the RB-AII cell synapse (Nakatsuka and Hamasaki, 1985; Dong and Hare, 2002a,b).

In the present study we analyzed the influence of ACh on signal processing in the classic rod pathway. We have found that GABA release from A17 cells can be elicited by activation of $n A C h R s$ and that this modulation regulates $\mathrm{RB}$ cell activity, a new mechanism by which retinal circuits shape visual responses under low light conditions.

\section{MATERIALS AND METHODS}

All experiments were performed on 30-50 day-old Sprague Dawley rats irrespective of sex. The rats, born and raised in the animal facility of the University of Valparaiso (Animal Welfare Assurance NIH A5823-01), were held at $20-25^{\circ} \mathrm{C}$ under a $12 \mathrm{~h}$ photoperiod with water and food ad libitum. The experimental procedures were approved by the bioethics committee of the University of Valparaiso and in accordance with the bioethics regulation of the Chilean Research Council (CONICYT).

\section{ELECTROPHYSIOLOGY}

After a period of dark adaptation $(\geq 1 \mathrm{~h})$, rats were decapitated under deep anesthesia and their eyes were removed and submerged in ACSF containing (mM) $119 \mathrm{NaCl}, 23 \mathrm{NaHCO}_{3}, 1.25$ $\mathrm{NaH}_{2} \mathrm{PO}_{4}, 2.5 \mathrm{KCl}, 2.5 \mathrm{CaCl}_{2}, 1.5 \mathrm{MgCl}_{2}, 20$ Glucose, $2 \mathrm{Na}-$ Pyruvate, 1 ascorbic acid (bubbled with a mixture of $95 \% \mathrm{O}_{2}-5 \%$ $\mathrm{CO}_{2}$ ). The retina was isolated and embedded in low melting point agarose $(3 \%)$, glued to a vibratome stage and sections of $\sim 200 \mu \mathrm{m}$ thickness were obtained. All slicing procedures were performed under dim red light and sections were kept in the dark at room temperature. Retinal slices were then transferred to a recording chamber in which they were superfused with ACSF $1-2 \mathrm{ml} / \mathrm{min}\left(\sim 30^{\circ} \mathrm{C}\right)$ supplemented with strychnine $(2 \mu \mathrm{M})$ to block glycine receptors. Cells were selected using a BX51WI microscope (Olympus, Japan) placed in a light tight enclosure and equipped with infrared differential interference contrast. Patch pipettes were pulled from borosilicate glass and had resistances of $\sim 5$ or $\sim 10 \mathrm{M} \Omega$ (for $\mathrm{AC}$ and $\mathrm{RB}$ cells recordings, respectively) when filled with an intracellular solution containing (mM) 125 cesium-methanesulfonate, 10 HEPES, 5 EGTA, $6 \mathrm{Na}_{2}$ ATP, 0.4 GTP, 15 TEA-Cl, $1 \mathrm{MgSO}_{4}$ (pH 7.4; osmolarity $\sim 294 \mathrm{mOsm}$ ) and 1\% Lucifer Yellow (Sigma Aldrich, St. Louis, MO, USA) or Alexa Fluor 488 (Invitrogen, USA). Signals were recorded using a PC-501A (Warner Instruments, Hamden, USA) or an EPC7-plus (HEKA Elektronik, Lambrecht, Germany) amplifier, digitized at $20 \mathrm{kHz}$ (PCI-6221, National Instruments, Austin, TX, USA) and stored using custom software written in IGOR PRO (Wavemetrics, Lake Oswego, OR, USA). Series resistance was below 20 or $30 \mathrm{M} \Omega$ for $\mathrm{AC}$ and $\mathrm{RB}$ cells respectively, and left uncompensated. Liquid junction potential was calculated to be $10 \mathrm{mV}$ and corrected off-line. ACs were kept at a holding membrane potential $\left(\mathrm{V}_{\text {hold }}\right)$ of $-60 \mathrm{mV}$ while IPSCs in $\mathrm{RB}$ cells were recorded at $0 \mathrm{mV}$. Cells were morphologically identified at the end of the experiment using the fluorescence image obtained with a digital camera (DS-MBWc, Nikon, Japan).

\section{CALCIUM IMAGING}

To record calcium signals from A17 cells, glass pipettes were frontfilled with normal intracellular solution and back-filled with the same solution supplemented with the calcium indicator Oregon Green 488 BAPTA-1 (OGB-1, 100-150 $\mu \mathrm{M}$, Molecular Probes, Eugene, OR, USA). After $\sim 15$ min, images were obtained using a CooLed illumination system (Cooledinc, Traverse City, MI, USA) and a Sensicam QE digital camera (Cooke Corp., Romulus, MI, USA). Data was acquired at $125 \mathrm{~Hz}$ and analyzed using custom software written in IGOR PRO.

\section{ELECTRORETINOGRAPHY}

Methods used for electroretinography have been described previously (Vielma et al., 2010). Briefly, animals were dark adapted for $2 \mathrm{~h}$ and anesthetized by halothane inhalation followed by injection of ketamine $(40 \mathrm{mg} / \mathrm{kg})$ and xylazine $(4 \mathrm{mg} / \mathrm{kg})$. Pupils were dilated using atropine (1\%) and lidocaine (1\%) was used as a topic anesthetic. Signals were recorded using a silver chloride ring electrode on the cornea and a subcutaneous platinum electrode in the eyelids as a reference. Animals were stimulated for $10 \mathrm{~ms}$ with a light spot of $1.5 \mathrm{~mm}$ of diameter, illuminance of $1.9 \mathrm{log}$ scot cd s m$~^{-2}$ and wavelength of $500 \mathrm{~nm}$. After recording control responses, animals were injected with the tested drugs dissolved in PBS using a 27-gauge needle through the ora serrata into the vitreous. Drug concentrations in the eye were calculated considering an average vitreal volume of $0.15 \mathrm{ml}$. ERG responses were measured again after $\sim 10 \mathrm{~min}$. Rats were finally sacrificed by an overdose of halothane.

\section{DRUGS AND SOLUTIONS}

ACh, choline, neostigmine, verapamil, nifedipine, 4-Chloromethyl-cresol, and ruthenium red were purchased from Sigma (St. Louis, MO, USA). Mecamylamine, dihydro- $\beta$ erythroidine, phenserine, TPMPA, SR95531, methyllycaconitine, tetramethylpiperidine-4-yl-heptanoate, tetrodotoxin (TTX), cyclopiazonic acid and strychnine were obtained from TOCRIS (Bristol, UK). Erysodine and cytisine were synthesized and kindly provided by Dr. Patricio Iturriaga from the Chemistry department of the Universidad de Chile. All drugs were dissolved as stock solutions in bi-distilled water or DMSO, and were diluted to the final concentration in control ACSF before the experiment. For localized puff applications, agonists were dissolved in HEPES-buffered ACSF in which $\mathrm{NaHCO}_{3}$ was substituted for HEPES. Puffs were applied into the (IPL) from glass pipettes with $\sim 1.5 \mu \mathrm{m}$ tip of inner diameter, using a custom-built picospritzer with 5 psi standard pressure. Specific nAChR agonists were loaded into one compartment of a puffer pipette pulled from borosilicate theta glass (World precision instruments, Sarasota, FL, USA) while the other was loaded with $\mathrm{ACh}$, achieving similar pressure ejection conditions for both compounds. Puff applications were separated by 3-6 min. Drugs added to the bath were superfused for a minimum time of $10 \mathrm{~min}$ before evaluating its effects. In a subset of experiments, tested drugs were washed-out ( $>30 \mathrm{~min}$ ) and recovery of 
responses from the treatment was evaluated (See Supplementary Table 1).

\section{DATA ANALYSIS}

Data analysis was performed in IGOR PRO. Input resistance $\left(\mathrm{R}_{\mathrm{in}}\right)$ was obtained by measuring the inverse slope of a linear fit to the current-voltage plots $(10 \mathrm{mV}$ steps from -120 to $-80 \mathrm{mV}$ ). Peak amplitude was measured after low-pass filtering at $1 \mathrm{kHz}$ for electrophysiological data or after filtering at $25 \mathrm{~Hz}$ and subtraction of background fluorescence for $\mathrm{Ca}^{2+}$ imaging signals. Electrical charge moved during a response was calculated as the integral of the baseline-subtracted response. Reversal potential of ACh evoked currents was calculated as the intercept of a line-fit of the peak amplitude values plotted against the corresponding $\mathrm{V}_{\text {hold }}$. Decay of evoked responses was fitted to a mono-exponential function. Frequency of spontaneous postsynaptic currents was quantified from 2-4 min recordings obtained during control conditions and immediately after arrival of the tested agents using automatic detection algorithms and manually reviewing the obtained results (Mini Analysis, Synaptosoft Inc., Decatur, GA, USA). Statistical analysis was performed using SigmaPlot (Systat software). After evaluation for normality using Shapiro-Wilk normality test, statistical significance was evaluated using two-tailed paired student's $t$-test. In Figures 6E,F, significant differences were tested using a repeated measures ANOVA and Bonferronicorrected paired comparisons. Except indicated, all experiments were compared to their own control. For comparing multiple treatments, a One-Way ANOVA or a Kruskal-Wallis One-Way ANOVA on ranks on the normalized changes was used, followed by post hoc pairwise comparison using Dunn's method. In Figures 1C, 3G, 4D, 5C, 6C bar plots represent percentage of control \pm standard error. In Figures $\mathbf{6 H}, \mathbf{I}$ and Figure S1G, bar plots depict mean frequency \pm standard error. Circles in bar plots show individual experiments. ${ }^{*}$ indicates $p<0.05,{ }^{* *} p<0.01$, and ${ }^{* * *} p<0.001$. Traces were filtered at $100 \mathrm{~Hz}$ for display purposes.

\section{RESULTS \\ ACETYLCHOLINE INDUCES GABAERGIC SIGNALING ONTO RB CELLS}

To study the influence of ACh on the rod pathway, we started by performing voltage clamp experiments in RB cells. These cells have their cell body generally located in the outer part of the INL and show sustained inward currents upon depolarization largely mediated by L-type VGCCs (Protti and Llano, 1998), allowing confirmation of their identity under whole cell voltage clamp (Figure 1A, right). Post hoc morphological examination revealed the characteristic RB cell features (Chávez et al., 2006), an axon traversing the entire IPL that narrowly extends axonal boutons close to the GC layer (Figure 1A, left). Application of ACh (1 mM, $1 \mathrm{~s})$ to the middle of the IPL induced outward currents in all RB cells tested ( $\mathrm{V}_{\text {hold }} 0 \mathrm{mV}, n=129$ ), which had a reversal potential close to the $\mathrm{Cl}^{-}$equilibrium potential $\left(\mathrm{E}_{\mathrm{Cl}}=-52.1 \mathrm{mV}\right.$, $\mathrm{E}_{\mathrm{rev}}=-54.5 \mathrm{mV}, n=5$, Figure 1B). Pharmacological analysis revealed that $A C h$-evoked currents were generated by the activation of $\mathrm{GABA}_{\mathrm{A}}(77 \pm 6 \%$ of control amplitude after SR95531 $10 \mu \mathrm{M}, n=12, p=0.008)$ and $\mathrm{GABA}_{\mathrm{C}}$ receptors $(29 \pm 3.3 \%$ of control after TPMPA $50 \mu \mathrm{M}, n=10, p=0.0025 ; 6.2 \pm 1.4 \%$ of control with SR95531 and TPMPA combined, $n=8, p=0.005$,

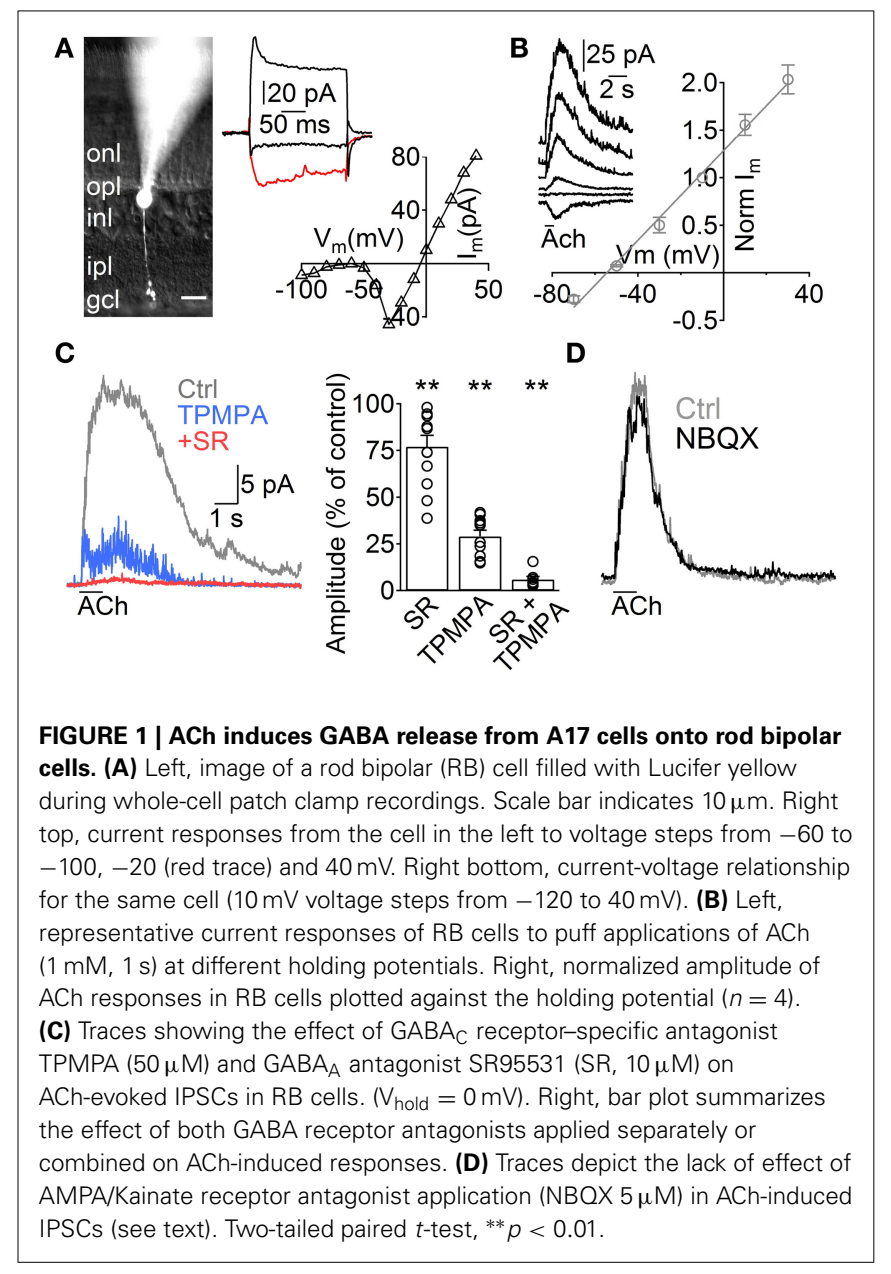

Figure 1C). Blocking AMPA and kainate receptors did not have a significant effect on the responses to ACh (NBQX $5 \mu \mathrm{M}, 94.2 \pm$ $2.9 \%$ of control, $n=5, p=0.2$, Figure 1D), suggesting they were generated by direct cholinergic activation of ACs presynaptic to RB cells.

\section{A17 CELLS MEDIATE ACh-INDUCED GABA RELEASE ONTO RB CELLS}

Although RB cells receive inputs from different GABAergic ACs, almost half of their inhibitory axonal contacts are reciprocal synapses with A17 cells (Strettoi et al., 1990; Kim et al., 1998). Therefore, we tested the possibility that these ACs generated the GABAergic IPSCs evoked by ACh in RB cells. A17 cells were selected in retinal slices by aiming at large oval-shaped cell bodies located in the inner part of the inner nuclear layer. During voltage clamp recordings, the low input resistance $(224 \pm 11 \mathrm{M} \Omega, n=$ 99) and nearly linear current-voltage relationship (Figure 2A, bottom) of A17 cells provided a reliable indicator of cell identity. Fluorescent images confirmed our physiological identification and showed the main morphological properties of A17 cells (Menger and Wässle, 2000), namely the presence of multiple thin dendrites bearing varicosities that radially extend toward the GCL border (Figure 2A). In all A17 cells tested, pulsed applications of ACh to the IPL induced strong inward currents (average amplitude $-215 \pm 12 \mathrm{pA}, \mathrm{V}_{\text {hold }}-60 \mathrm{mV}, n=98$, Figure 2B) 
and a mean depolarization of $33.6 \pm 3.7 \mathrm{mV}$ in current clamp recordings $(n=5$, membrane resting potential $-61.6 \pm 1 \mathrm{mV}$, Figure 2B, inset). Currents evoked by ACh reversed at $5.5 \mathrm{mV}$ ( $n=4$; Figure 2B, right) and were insensitive to synaptic block by divalent VGCC blockers (100.9 $\pm 5.7 \%$ of control response with $\mathrm{Cd}^{2+} 200 \mu \mathrm{M}, n=5, p=1$, Figure 2B left; $98.7 \pm 4.1 \%$ of control with $\mathrm{Co}^{2+} 1 \mathrm{mM}, n=4, p=0.65$, Figure S1A) or inhibition of AMPA/kainate receptors (NBQX $5 \mu \mathrm{M}, 116.5 \pm 8.6 \%$, $n=3, p=0.42$, Figure S1B), demonstrating their postsynaptic origin. ACh-evoked responses only mildly desensitize at the concentrations tested, as shown by the fact that a second application of ACh after a $2 \mathrm{~s}$ interval triggered currents with an amplitude of $56.5 \pm 6.6 \%$ of the control response ( $n=3$; Figure $2 \mathrm{C}$ ).

Interestingly, other populations of ACs also displayed inward currents when either ACh or nicotine was applied (69 out of 206 non-A17 ACs tested, data not shown). These cells formed a heterogeneous population displaying different morphological and physiological properties indicating that cholinergic modulation of inhibition is a widespread phenomenon in the rat retina. However, isolation of GABAergic IPSCs from A17 onto RB cells with TTX ( $1 \mu \mathrm{M}$, Chávez et al., 2006) left postsynaptic ACh responses unchanged ( $93 \pm 12 \%$ of control, $p=$ $0.2, n=6$; Figure 2D). In summary, we have found that AChevoked GABAergic IPSCs in RB cells are mostly generated by GABA released from A17 cells after the activation of functional cholinergic receptors.

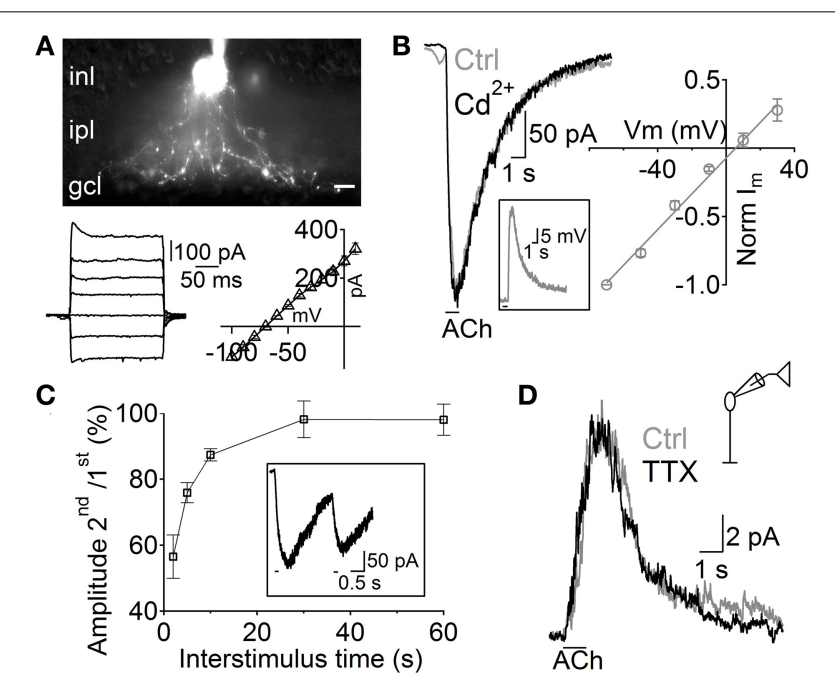

FIGURE 2 | Depolarization of A17 cells mediates acetylcholine evoked IPSCs in RB cells. (A) top, image of an A17 cell filled with Lucifer yellow during whole-cell patch clamp. Scale bar indicates $10 \mu \mathrm{m}$. Bottom, (left) responses of the $A 17$ cell to voltage steps from -100 to $20 \mathrm{mV}(20 \mathrm{mV}$ steps) and (right) plot of its current-voltage relationship. (B) Representative trace of $A C h-e v o k e d$ currents in $A 17$ cells $\left(V_{\text {hold }}-60 \mathrm{mV}\right)$ which were unaffected by calcium channel blockage with $\mathrm{Cd}^{2+}(200 \mu \mathrm{M})$. Inset shows the response of an $\mathrm{A} 17$ cell to $\mathrm{ACh}$ in current clamp mode. Right, normalized amplitude of ACh responses in A17 cells plotted against holding potential $(n=4)$. (C) Summary of paired responses to ACh (1 mM, $100 \mathrm{~ms}$ ) with different inter-stimulus intervals. Inset shows the response to a paired stimulus separated by $2 \mathrm{~s}$. (D) ACh-evoked IPSCs in rod bipolar cells were insensitive to perfusion of tetrodotoxin (TTX $1 \mu \mathrm{M}, n=7$ ) suggesting that GABA is released from A17 cells (Chávez et al., 2010).

\section{PHARMACOLOGY OF A17 CELL nAChRs}

$\mathrm{ACh}$ is the natural agonist of metabotropic and ionotropic cholinergic receptors. Given that both can be found in the mammalian retina (Wassélius et al., 1998; Keyser et al., 2000; Marritt et al., 2005), we asked which of these receptor types mediates the release of GABA from A17 cells. In agreement with their cationic nature, ACh-induced currents in A17 cells were effectively reduced by the general $\mathrm{nAChR}$ antagonist mecamylamine $(\mathrm{Mec} 2 \mu \mathrm{M}, 15.4 \pm$ $1.5 \%$ of control, $n=17, p=0.00004$ ) but unaffected by the muscarinic antagonist scopolamine (Sco $10 \mu \mathrm{M}, 107.4 \pm 12.4 \%$ of control, $n=4, p=0.58$; Figures 3A,B left, G). Moreover, nicotine also effectively elicited inward currents in A17 cells (Nicotine $1 \mathrm{mM}, 500 \mathrm{~ms},-199.6 \pm 33 \mathrm{pA}, n=10$, Figure 5D, middle). Consequently, IPSCs evoked after ACh application in RB cells were completely abolished by mecamylamine $(6.7 \pm 3.6 \%$ of

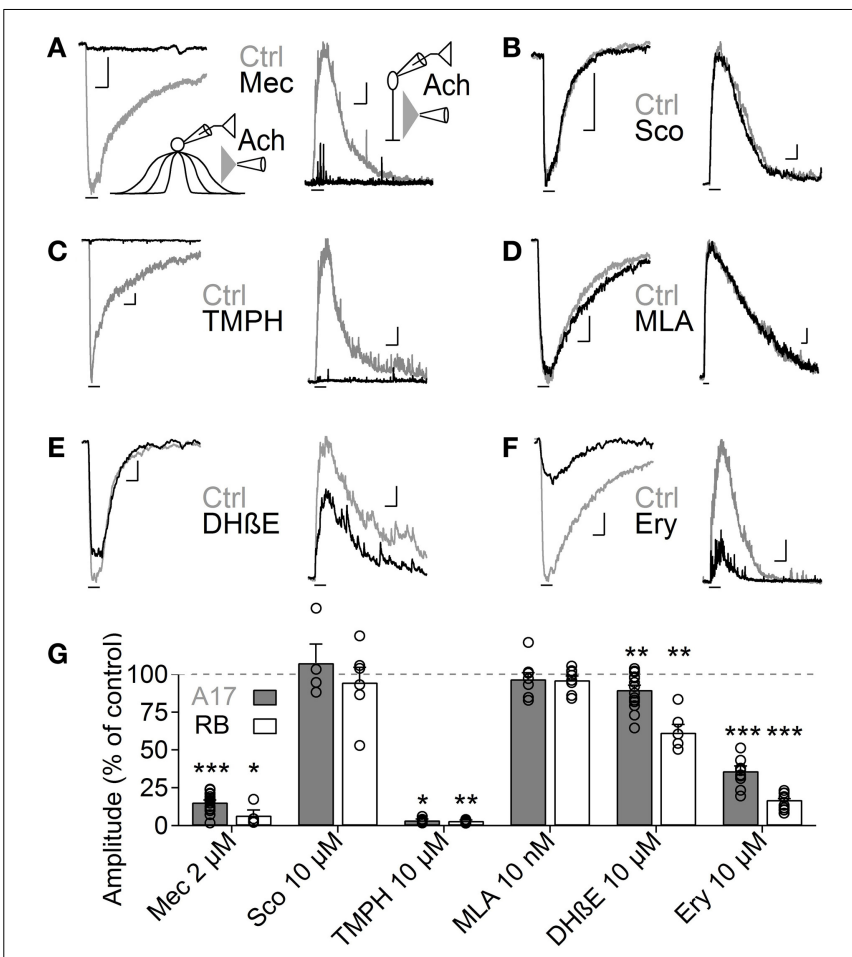

FIGURE 3 | Heteromeric nAChRs cells mediate ACh responses in A17 and $\mathbf{R B}$ cells. (A-F) Representative traces of current responses induced by localized puffs of ACh (1 mM, 1 s) at the IPL in A17 (left) and in RB cells (right) in control conditions and in the presence of $(\mathbf{A})$ the nicotinic receptor blocker mecamylamine (Mec $2 \mu \mathrm{M}$ ), (B) muscarinic receptor antagonist scopolamine (Sco $10 \mu \mathrm{M}$ ), (C) heteromeric $\mathrm{nAChR}$ antagonist tetramethylpiperidine-4-yl-heptanoate (TMPH $10 \mu \mathrm{M})$, (D) homomeric $\mathrm{nAChR}$ antagonist methylcaconitine (MLA $10 \mathrm{nM}$ ) or $\alpha_{4} \beta_{2}$ antagonists (E) dihydro- $\beta$-erythroiodine (DH $\beta E 10 \mu \mathrm{M})$ and (F) erysodine (Ery $10 \mu \mathrm{M})$. Vertical scale bars represent $50 \mathrm{pA}$ for $\mathrm{A} 17$ cell responses and $5 \mathrm{pA}$ for RB cell traces, and horizontal bars depict $1 \mathrm{~s}$ of time. (G) Bar graph summarizing the effects of cholinergic receptor antagonists on the ACh-induced currents in A17 (gray bars) and RB cells (white bars). Two-tailed paired $t$-tests, $* p<0.05,{ }^{* *} p<0.01$, and ${ }^{* * *} p<0.001$. For A17 cells, significant differences were observed between Mec and TMPH if tested vs. the effects of Sco, MLA or DH $\beta E$. For RB cells, differences were significant when comparing the influence of Mec and TMPH vs. Sco or MLA (One-Way ANOVA on ranks and Dunn's method for multiple comparisons). 
control, $n=4, p=0.04)$ while scopolamine had no significant effect ( $94.8 \pm 9.9 \%$ of control, $n=6, p=0.9$; Figures 3A,B right, G). Thus, A17 cells of the rat retina express functional nAChRs.

Nicotinic receptors are assembled by different combinations of $\alpha$ and $\beta$ subunits. The precise subunit composition defines important receptor properties such as ligand affinity, channel kinetics and ionic selectivity (Alkondon and Albuquerque, 1993), greatly affecting the influence that nAChR activation will have in cellular function. To investigate which $\mathrm{nAChR}$ subtypes are expressed in A17 cells and mediate postsynaptic responses in RB cells, we tested the effects of specific nicotinic pharmacological agents. Perfusion of an antagonist specific for neuronal heteromeric nAChRs (tetramethylpiperidine-4-yl-heptanoate [TMPH] $10 \mu \mathrm{M}$, Damaj et al., 2005; Papke et al., 2005) abolished ACh responses in both cell types $(3.6 \pm 0.7 \%$ of control in A17 cells, $n=5$, $p=0.02 ; 3.2 \pm 0.4 \%$ of control in RB cells, $p=0.008, n=$ 5, Figures 3C,G), while homomeric nAChR-specific antagonist methyllycaconitine (MLA) did not produce a significant effect neither in A17 nor in RB cells $(10 \mathrm{nM} ; 96.8 \pm 4.2$ and $96.7 \pm$ $2.7 \%$ of control responses, $p=0.25$ and 0.17 respectively, $n=8$ for both cells types, Figures 3D,G). One of the most commonly expressed heteromeric nAChRs in the CNS is the $\alpha_{4} \beta_{2}$ subtype (Dani and Bertrand, 2007). The prototypical $\alpha_{4} \beta_{2}$ nAChR antagonist dihydro- $\beta$-erythroiodine (DH $\beta$ E $10 \mu \mathrm{M}$, Harvey et al., 1996) produced a small albeit significant reduction of AChinduced currents in A17 cells (89.7 $\pm 3 \%$ of control, $n=15, p=$ $0.009)$ and a marked decrease in RB cell responses (61 $\pm 5.3 \%$ of control, $n=6, p=0.003$; Figures $3 E, G)$. Erysodine $(10 \mu \mathrm{M})$, another alkaloid with high affinity for $\alpha_{4} \beta_{2}$ nAChRs (Decker and Anderson, 1995; Iturriaga-Vásquez et al., 2010), had a more pronounced effect in A17 and RB cells (36.1 $\pm 3.3 \%$ of control in A17 cells, $n=10, p=0.0002 ; 17 \pm 0.8 \%$ of control in RB cells, $n=10, p=0.00003$; Figures 3F,G) but did not completely block the response to ACh. Pharmacology of nicotinic receptors in A17 cells was further investigated by comparing ACh-evoked currents with those induced by specific nicotinic agonists. Choline (Chol, $1 \mathrm{mM}$ ), a byproduct of ACh cleavage and an $\alpha_{7}$-nAChR-specific ligand (Alkondon and Pereira, 1999), produced only a marginal response in A17 cells and had no discernible effect in $\mathrm{RB}$ cells $(10.1 \pm 3.9$ and $2.5 \pm 2 \%$ of ACh-evoked responses respectively, $n=5$ for both cell types, $p=0.03$ and 0.017 ; Figures 4A,D). Likewise, an agonist with specificity for $\alpha_{4} \beta_{2}$ nAChRs (RJR-2403 $100 \mu \mathrm{M}$, Papke et al., 2000) failed to activate either A17 or RB cells $(7.5 \pm 5 \%$ and $1.7 \pm 0.6 \%$ of ACh response, $n=4$ and 3 , $p=0.009$ and 0.004 , respectively; Figures 4B,D). On the contrary, the $\beta_{4}$ subunit-specific nicotinic agonist cytisine (100 $\mu \mathrm{M}$; Luetje and Patrick, 1991; Papke and Heinemann, 1994) induced currents in A17 and RB cells comparable to those evoked by ACh $(108.7 \pm 14.7 \%$ and $113.3 \pm 22.1 \%$ of $\mathrm{ACh}$ responses respectively, $n=5$ for both cell types, $p=0.58$ and 0.97 ; Figures 4C,D), although with a slower decay (tau $3.9 \pm 0.3$ vs. $28.7 \pm 4.9 \mathrm{~s}$, for ACh vs. cytisine-evoked currents in A17 cells, $n=5, p=0.047$ ). In summary, ACh responses in both cell types have a comparable pharmacological profile, further supporting that A17 cells through activation of heteromeric $\mathrm{nAChRs}$, provide the majority of the ACh-triggered GABA release onto RB cells.

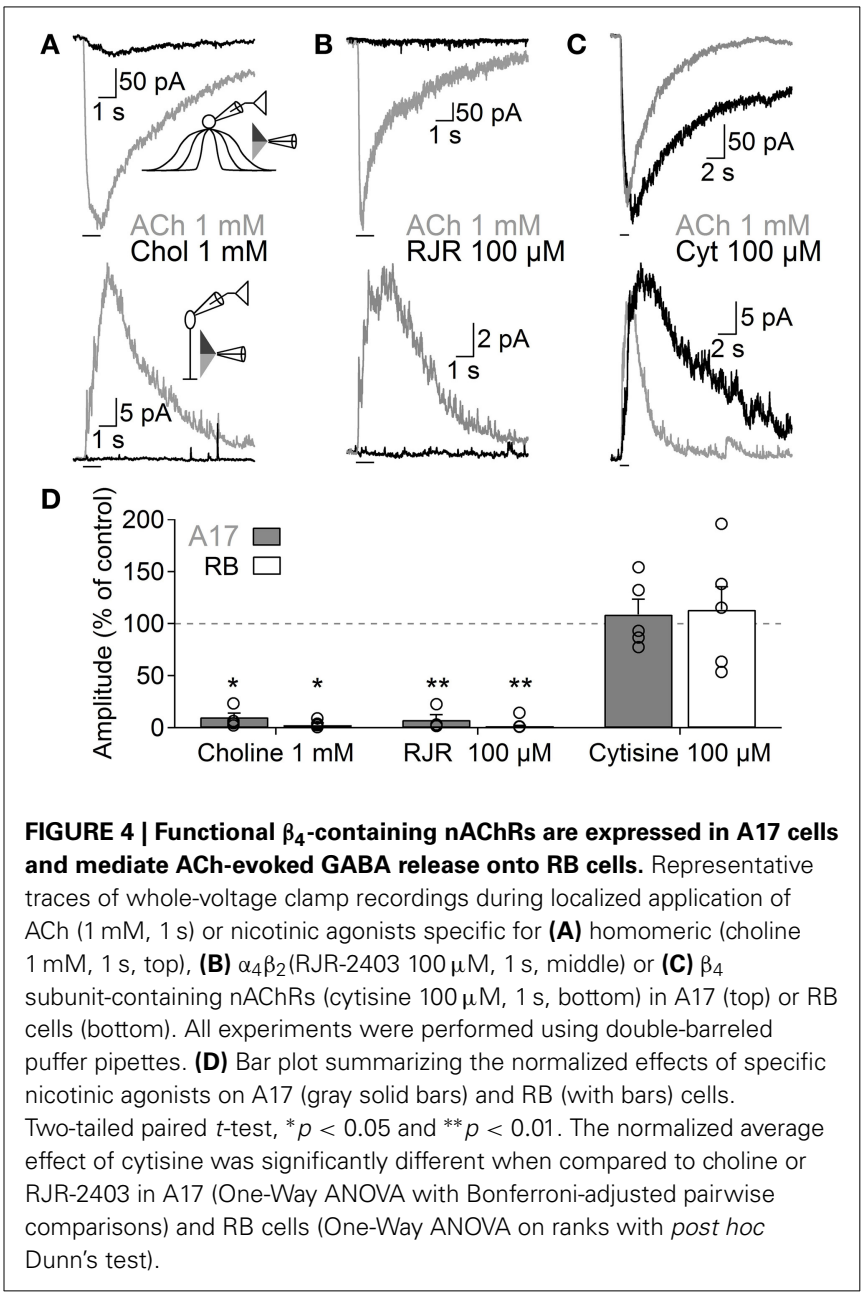

\section{MECHANISMS OF ACh-EVOKED GABA RELEASE}

Next, we investigated the mechanisms through which nAChR activation induces $\mathrm{Ca}^{2+}$ entry into A17 cells, by studying AChevoked IPSCs in RB cells. Perfusion with $\mathrm{Ca}^{2+}$-free solutions importantly reduced the amplitude of ACh-evoked IPSCs in RB cells $\left(0 \mathrm{Ca}^{2+}, 29.5 \pm 6 \%\right.$ of control, $n=4, p=0.015$, Figures $5 \mathrm{~A}$ left, C; $0 \mathrm{Ca}^{2+}+1 \mathrm{mM}$ EGTA, $25.3 \pm 5.2 \%$ of control, $n=4$, $p=0.003$, Figures S1C, 5C). Because heteromeric nAChRs form channels with relatively low $\mathrm{Ca}^{2+}$ permeability (Fucile, 2004), $\mathrm{Ca}^{2+}$ influx should be provided by a different membrane conductance. Indeed, general blockers of VGCCs effectively reduced the response of RB cells to ACh $\left(\mathrm{Cd}^{2+} 200 \mu \mathrm{M}, 14.5 \pm 2.8 \%\right.$ of control, $n=9, p=0.001$, Figures 5A middle, C; $\mathrm{Co}^{2+} 1 \mathrm{mM}, 19.5 \pm$ $1.2 \%$ of control, $n=4, p=0.01$, Figures S1D, 5C). More specifically, inhibition of L-type VGCCs, which are known to be present in synaptic varicosities of A17 cells (Grimes et al., 2009), almost completely abolished ACh responses (verapamil $20 \mu \mathrm{M}, 7.3 \pm$ $1.4 \%$ of control, $n=5, p=0.02$, Figures 5A right, C; nifedipine $30 \mu \mathrm{M}, 17 \pm 3.7 \%$ of control, $n=5, p=0.0007$, Figures S1E, 5C). This indicates a prevalent role of L-type VGCCs in cholinergic release of GABA from A17 cells, contrary to their limited participation when glutamate is the excitatory neurotransmitter (verapamil $20 \mu \mathrm{M}, 91.8 \pm 4.1 \%$ of control responses to glutamate 


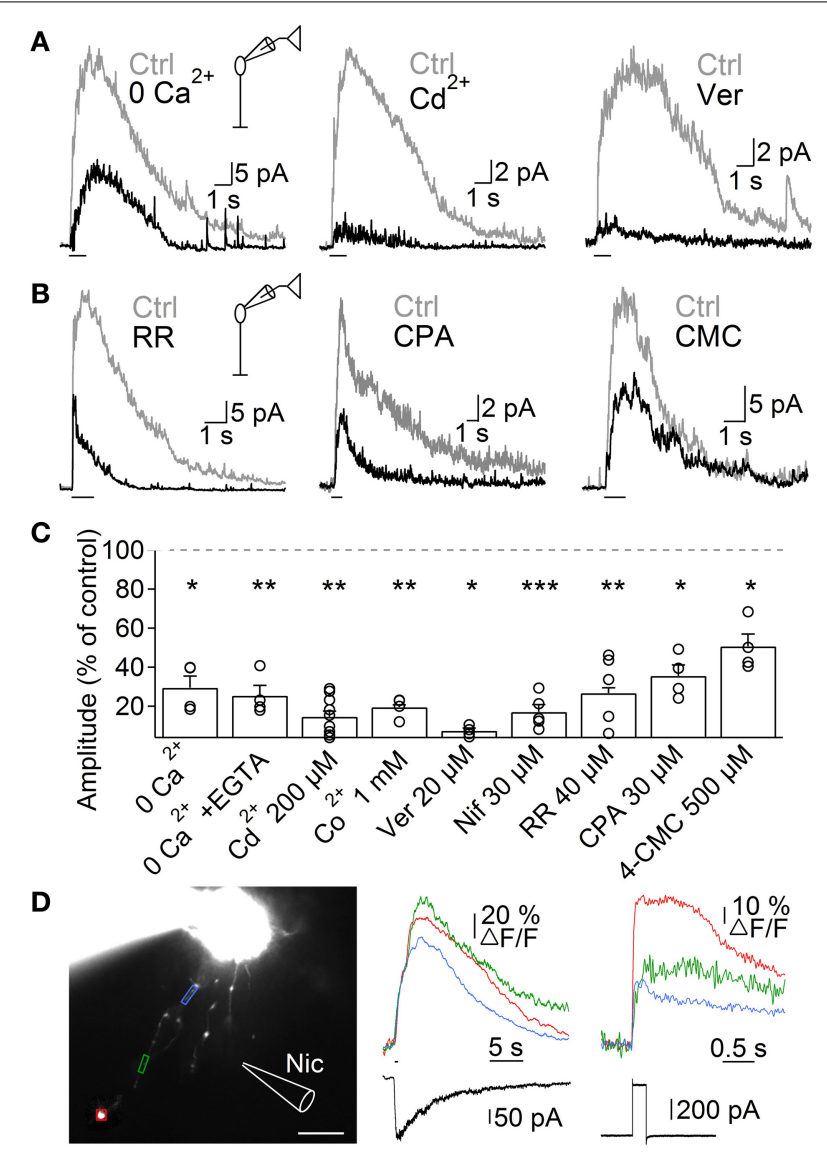

FIGURE 5 | Mechanisms of ACh-induced GABA release from A17 cells. (A) Representative traces of ACh-evoked IPSCs in RB cells (1 mM, 1s) in control conditions and after (left) removing extracellular $\mathrm{Ca}^{2+}$, (middle) applying the unspecific VGCC blocker $\mathrm{Cd}^{2+}(200 \mu \mathrm{M})$ or (right) after specific blockade of L-type VGCCs with verapamil $(20 \mu \mathrm{M})$. (B) Traces showing the effects of disrupting intracellular calcium signaling by (left) a blocker of ryanodine receptor channels (ruthenium red, RR $40 \mu \mathrm{M}$ ), (middle) an inhibitor of the endoplasmic reticulum $\mathrm{Ca}^{2+}$-ATPase pump (cyclopiazonic acid, CPA $30 \mu \mathrm{M}$ ) and (right) an agonist of ryanodine receptors

(4-chloro-m-cresol, 4-CMC $500 \mu \mathrm{M}$ ) on the responses to ACh in RB cells.

(C) Bar graph displaying normalized average ACh response amplitudes in $\mathrm{RB}$ cells after perfusion with solutions affecting presynaptic calcium dynamics. ${ }^{*} p<0.05$, ${ }^{* *} p<0.01$, and ${ }^{* * *} p<0.001$, for two-tailed paired $t$-tests. Differences between groups were significant when verapamil was compared with CPA or 4-CMC, and when $\mathrm{Cd}^{2+}$ is compared with 4-CMC (One-Way ANOVA on ranks with post hoc Dunn's test). (D) Left, montage of images from an A17 cell filled with $100 \mu$ M OGB-1 (scale bar $10 \mu \mathrm{m}$ ). Analyzed regions of interest are denoted by colored frames and correspond to $\mathrm{Ca}^{2+}$ responses traces after (middle) puff application of nicotine (Nic $1 \mathrm{mM}, 500 \mathrm{~ms}$ ) or (right) after a $60 \mathrm{mV}$ voltage step of $200 \mathrm{~ms}$ duration. Bottom, black traces show current responses after the respective stimulation paradigms.

[200 $\mu \mathrm{M}, 200 \mathrm{~ms}$ ], $n=3$, Figure S1F; see also Chávez et al., 2006; Grimes et al., 2009). On the other hand, $\mathrm{Ca}^{2+}$-induced $\mathrm{Ca}^{2+}$ release (CICR) from intracellular stores could also contribute by enhancing the cytoplasmatic $\mathrm{Ca}^{2+}$ concentration after an initial influx of the ion, as reported for glutamate-evoked GABA release from A17 cells (Chávez et al., 2006; Chávez and Diamond, 2008). Indeed, perfusion with an antagonist of ryanodine receptors produced a significant decrease in the amplitude of IPSCs triggered by $\mathrm{ACh}$ (ruthenium red, RR $40 \mu \mathrm{M}, 26.7 \pm 3 \%$ of control, $n=5, p=0.002$; Figures 5B left, C). Consistently, depletion of $\mathrm{Ca}^{2+}$ from the endoplasmic reticulum using the $\mathrm{Ca}^{2+}$-ATPase antagonist cyclopiazonic acid (CPA $\left.30 \mu \mathrm{M}\right)$ or the ryanodine receptors agonist 4-chloro-methyl-cresol (4-CMC $500 \mu \mathrm{M})$ significantly diminished IPSCs evoked by ACh in RB cells $(35.5 \pm 5.6 \%$ and $50.4 \pm 6.3 \%$ of control response, $p=0.043$ and 0.049 , respectively, $n=4$ for both conditions; Figures 5B,C).

To further confirm that activation of nAChRs induced $\mathrm{Ca}^{2+}$ accumulation in these ACs, we loaded A17 cells with the high affinity $\mathrm{Ca}^{2+}$-sensitive dye OGB-1, and imaged the response to nicotine puff applications. Nicotine generated strong and long lasting calcium signals (Figure 5D) that were significantly larger when measured at regions of interest that included dendritic varicosities compared to portions devoid of them $(\Delta \mathrm{F} / \mathrm{F}=42 \pm 9.4$ vs. $23.7 \pm 8.2 \%, n=9, p=0.004$; Figure $5 \mathrm{D}$, middle). Nicotineinduced calcium transients were similar in amplitude to those evoked by a depolarization step $(60 \mathrm{mV}, 200 \mathrm{~ms}, 44.8 \pm 14.8$ vs. $46.2 \pm 8.9 \%$ of $\Delta \mathrm{F} / \mathrm{F}, n=5$, Figure $5 \mathrm{D}$, right), indicating that activation of $\mathrm{nAChRs}$ has a strong depolarizing effect.

Altogether, these findings support the notion that nAChRmediated depolarization of A17 cells activates L-type VGCCs and CICR, resulting in $\mathrm{Ca}^{2+}$ accumulation that finally drives GABA release onto RB cells.

\section{GABA RELEASE FROM A17 CELLS IS MODULATED BY ENDOGENOUS ACh IN VITRO AND IN VIVO}

Although we have demonstrated that ACh application has important effects on GABAergic inputs to RB cells, it remains to be shown whether endogenous $\mathrm{ACh}$ is able to modulate A17-RB cell signaling. For this purpose we analyzed the effects of acetylcholinesterase (AChE) inhibitors on A17 and RB cell activity. Perfusion with neostigmine or phenserine induced a marked increase in the electrical charge moved during ACh-induced responses in A17 (neostigmine $2 \mu \mathrm{M}, 641 \pm 114 \%$ of control, $n=7, p=0.005$; phenserine $5 \mu \mathrm{M}, 262 \pm 22 \%, n=4, p=$ 0.039 , Figures 6A,C) and RB cells (neostigmine $2 \mu \mathrm{M}, 698.8 \pm$ $197 \%, n=10, p=0.0005$, Figures 6B,C), demonstrating that $\mathrm{AChE}$ actively cleaves $\mathrm{ACh}$ in rat retinal slices. Interestingly, application of neostigmine alone was able to significantly depolarize A17 cells (neostigmine $2 \mu \mathrm{M}$, from $-61.4 \pm 0.9$ to $-53.2 \pm$ $1.8 \mathrm{mV}, n=5, p=0.0041)$. This depolarization was mediated by $\mathrm{nAChR}$ activation as it was reversed to near-control values by subsequent perfusion with TMPH (neostigmine $2 \mu \mathrm{M}+$ TMPH $10 \mu \mathrm{M},-60.4 \pm 1.2 \mathrm{mV}, n=3, p=0.01$, Figures 6D,E). Similarly, during voltage-clamp recordings from a different set of cells, AChE inhibitors induced long-lasting inward currents (neostigmine $2 \mu \mathrm{M}$, from $12.5 \pm 11.8 \mathrm{pA}$ to $-20.5 \pm 11.9 \mathrm{pA}$, $n=7, p=0.012$; phenserine $5 \mu \mathrm{M}, 0.8 \pm 7.1 \mathrm{pA}$ to $-24.9 \pm 5.9$ $\mathrm{pA}, n=5, p=0.04$, Figure $6 \mathrm{~F}$ ). The observed effects of AChE inhibitors were not accompanied by an apparent increase in EPSC frequency, suggesting that nAChRs in A17 cells might be non-synaptically activated. Indeed, the frequency of spontaneous EPSCs during inhibition of AMPA/Kainate receptors (NBQX $5 \mu \mathrm{M})$ did not change after perfusion of a specific nicotinic 


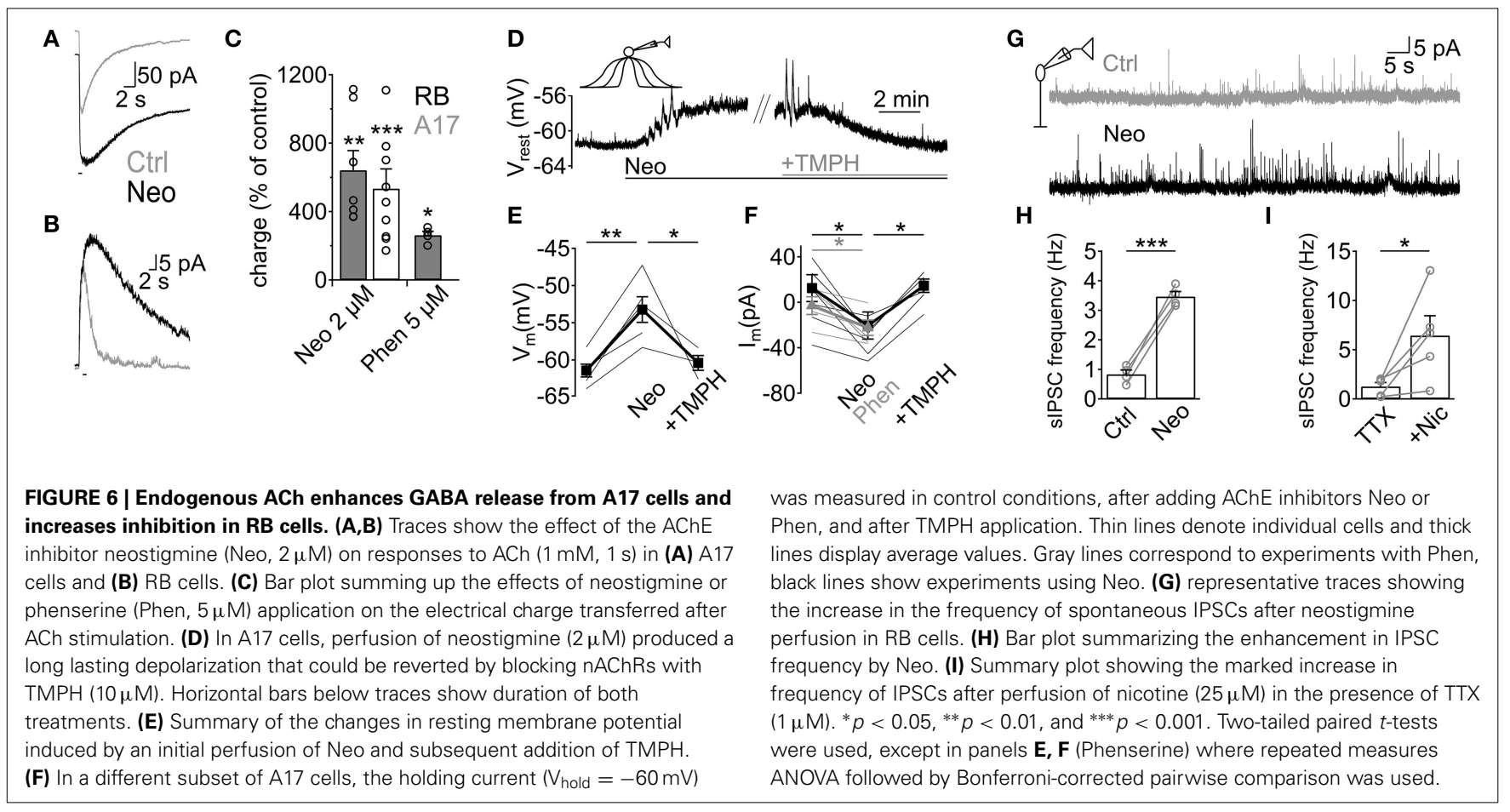

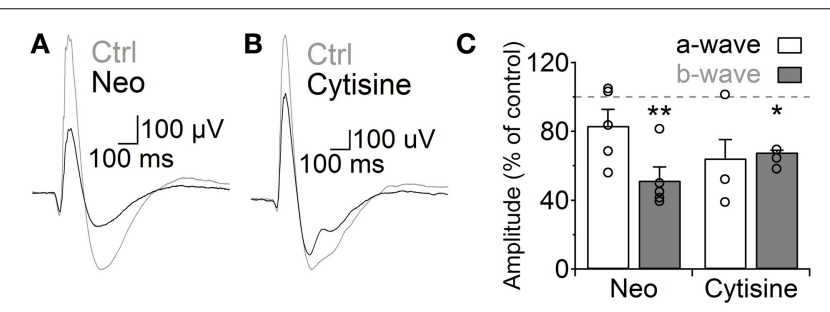

FIGURE 7 | Activation of nicotinic receptors reduces the rod bipolar-driven $b$-wave of the scotopic electroretinogram. (A,B) representative traces of the scotopic flash ERG response in control conditions and after intravitreal injection of $(\mathbf{A})$ neostigmine $(25 \mu \mathrm{M})$ or $(\mathbf{B})$ the specific nAChR agonist cytisine $(500 \mu \mathrm{M})$. (C) Bar graph showing average changes in the scotopic ERG a- and b-waves after neostigmine or cytisine injections. Two-tailed paired $t$-test, ${ }^{*} p<0.05$ and ${ }^{* *} p<0.01$.

antagonist $(0.54 \pm 0.18 \mathrm{~Hz}$ during NBQX vs. $0.6 \pm 0.3 \mathrm{~Hz}$ after $\mathrm{TMPH}+\mathrm{NBQX}, n=4, p=0.63$, Figure S1G), showing the absence of spontaneous nAChR-mediated synaptic events in A17 cells. In RB cells neostigmine increased the frequency of spontaneous IPSCs about 5 fold (from $0.8 \pm 0.1$ to $3.5 \pm 0.2 \mathrm{~Hz}, n=4$, $p=0.0008$, Figures $6 \mathrm{G}, \mathbf{H})$. A similar result could be observed when low concentrations of nicotine were applied in the presence of TTX (Nicotine $25 \mu \mathrm{M}$, from $1.2 \pm 0.4$ to $6.4 \pm 2 \mathrm{~Hz}, n=5$, $p=0.047$, Figure 6I) indicating that these enhancements in IPSC frequency by nicotine and neostigmine are caused by increased GABA release from A17 cells. In summary, these results demonstrate that in the slice preparation under scotopic conditions, $\mathrm{ACh}$ is intrinsically released reaching concentrations which are high enough to depolarize A17 cells and boost synaptic GABAergic neurotransmission.
Finally, we analyzed how the increase in GABAergic signaling mediated by $\mathrm{ACh}$ and $\mathrm{nAChRs}$ affects light responses of RB cells. We addressed this question using the in vivo scotopic flashevoked ERG. Intravitreal injection of neostigmine produced a marked decrease in the ERG b-wave amplitude (Neo $25 \mu \mathrm{M}$, $51.5 \pm 7.7 \%$ of control, $n=5, p=0.005)$, which mainly represents RB cell depolarization (Weymouth and Vingrys, 2008), without significantly altering the photoreceptor-mediated a-wave $(83.3 \pm 9.5 \%$ of control, $n=5$; Figures 7A,C). Similarly, injection of cytisine produced a significant reduction in the b-wave (cytisine $500 \mu \mathrm{M}, 64.1 \pm 1.8, n=3, p=0.006$; Figures 7B,C) and a non-significant decrease in the a-wave $(p=0.199)$. This indicates that $\mathrm{ACh}$ modulates $\mathrm{RB}$ cell light responses in vivo through the activation of nAChRs.

\section{DISCUSSION}

Neuronal activity in the inner retina is shaped by a wide variety of GABAergic and glycinergic ACs, which form numerous inhibitory synapses with bipolar and GCs, and provide feedback and feed-forward inhibition to the inner retinal circuitry (Macneil and Masland, 1998; Wässle, 2004; Masland, 2012). The overall excitability of the network is also under the influence of neuromodulators acting on different types of cells in a slower time scale, enhancing the flexibility of the system (Marc, 2004; Witkovsky, 2004; Huang et al., 2013). RB cell output is controlled by a diverse and heterogeneous set of inhibitory inputs (Eggers and Lukasiewicz, 2006; Eggers et al., 2007; Chávez and Diamond, 2008; Chávez et al., 2010), but reciprocal synapses with A17 cells (Hartveit, 1999; Singer and Diamond, 2003; Chávez et al., 2006) are the most numerous (Strettoi et al., 1990; Kim et al., 1998). The present study describes a novel modulatory mechanism of A17 cell activity mediated by ACh and heteromeric nAChRs. 


\section{SUBUNIT COMPOSITION OF nAChRS IN A17 CELLS}

Nicotinic receptors comprise a heterogeneous family formed by different combinations of $\alpha$ and $\beta$ subunits (Dani and Bertrand, 2007; Millar and Gotti, 2009). Biochemical evidence suggests that retinal $\mathrm{nAChRs}$ are assembled as complex combinations of $\alpha_{2}-$ $\alpha_{6}$ and $\beta_{2}-\beta_{4}$ subunits (Moretti et al., 2004; Marritt et al., 2005). Using pharmacological agents which are subunit-specific at the concentrations used (Alkondon and Albuquerque, 1993; Harvey and Luetje, 1996; Papke et al., 2000), we demonstrate here that A17 cells do not express the commonly found $\alpha_{7}$ or $\alpha_{4} \beta_{2}$ nAChRs. Instead, the strong response to the agonist cytisine (Alkondon and Albuquerque, 1993; Papke and Heinemann, 1993; Takeda et al., 2003; Smith and Uteshev, 2008) as well as the complete block exerted by TMPH (Decker and Anderson, 1995; Damaj et al., 2005; Papke et al., 2005) suggest that these nAChRs contain the $\beta_{4}$ subunit. Particularly, the low efficacy of DH $\beta E$ in blocking ACh-induced currents and the failure of RJR-2403 to evoke responses in A17 or RB cells, indicate that nAChRs in A17 amacrine cells might be of the $\alpha_{3} \beta_{4}$ subtype (Harvey and Luetje, 1996; Papke et al., 2000). This pharmacological characterization is further supported by immunohistochemical data that failed to demonstrate $\alpha_{3} \beta_{2}$ or $\alpha_{7}$ nAChRs in rabbit A17-homologous cells (Keyser et al., 2000; Dmitrieva et al., 2007, 2003). Finally, nAChRs mediating ACh-evoked responses in A17 cells had low $\mathrm{Ca}^{2+}$ permeability and showed slow kinetics and weak desensitization (Figures 2, 5), in agreement with the properties of $\beta_{4}$ subunitcontaining nAChR channels (Papke and Heinemann, 1994; Quick et al., 1999; Takeda et al., 2003; Fucile, 2004). Therefore, our data are consistent with the interpretation that A17 cells of the rat retina express heteromeric nAChRs that contain the $\beta_{4}$ subunit, although further experiments are necessary to determine the exact composition of these receptors. Interestingly, the pharmacology of Ach-induced GABA release into RB cells closely resembles that of inward currents observe in A17 AC, supporting their prevalence in this modulatory mechanism. Nevertheless, GABA release was more affected by nicotinic antagonists than A17 cell ACh-induced inward currents (Figure 3) and less sensitive to agonists (Figure 4), suggesting that a minimum depolarization of A17 terminals by $\mathrm{ACh}$ is required to trigger synaptic release.

\section{MECHANISM OF ACh-INDUCED INHIBITION OF RB CELLS}

Reciprocal feedback to RB cells depends on calcium flow through $\mathrm{Ca}^{2+}$-permeable AMPA receptors (CP-AMPARs) and postsynaptic $\mathrm{GABA}_{\mathrm{A}}$ receptors (Singer and Diamond, 2003; Chávez et al., 2006, 2010). BK channels present in A17 cell varicosities curtail CP-AMPAR-mediated depolarization and limit L-type VGCCs involvement in GABA release (Grimes et al., 2009). Nevertheless, strong or long-lasting glutamate drive depolarizes A17 cells sufficiently to overcome BK channel inhibition and engage VGCCs in release events (Grimes et al., 2009) that activate both GABA receptor subtypes (Hartveit, 1999; Dong and Hare, 2002a,b; Singer and Diamond, 2003; Eggers et al., 2007; Chávez et al., 2010). NAChRs can influence neurotransmitter release through a variety of mechanisms, including direct $\mathrm{Ca}^{2+}$ influx through the channel, recruitment of VGCCs by membrane depolarization or through intracellular $\mathrm{Ca}^{2+}$ release (Vizi and Lendvai, 1999; Dajas-Bailador and Wonnacott, 2004). We have shown that ACh-induced GABA release in A17 cells is mainly mediated by L-type VGCCs and CICR (Figure 5) and preferentially activates $\mathrm{GABA}_{\mathrm{C}}$ receptors on $\mathrm{RB}$ cells (Figure 1). Cholinergic recruitment of VGCCs in A17 cells will be facilitated by the low $\mathrm{Ca}^{2+}$ permeability (avoiding early activation of BK channels) and slow kinetics of A17 nAChRs. Interestingly, these previous observations suggest a correlation between VGCCs-mediated $\mathrm{Ca}^{2+}$ entry in $A 17$ cells and postsynaptic $\mathrm{GABA}_{C}$ receptors. Considering that $G_{A B A}$ and $G_{A B A}$ receptors are spatially segregated in the RB cell axon (Fletcher et al., 1998; Koulen et al., 1998; Chávez et al., 2010), it is tempting to hypothesize that there are different classes of release sites within A17 cells and that ACh induces GABA release preferentially from those presynaptic to $\mathrm{GABA}_{\mathrm{C}}$ receptors. Our measurements showed that $\mathrm{Ca}^{2+}$ signals evoked by $\mathrm{ACh}$ were stronger in regions containing varicosities, following the distribution of L-type VGCCs in A17 cells (Grimes et al., 2009). It would be interesting to analyze the subcellular localization of $\mathrm{nAChRs}$ in A17 cells in relation to VGCCs and postsynaptic GABA receptors to better understand the mechanisms of action of this nicotinic modulation of retinal GABAergic signaling.

\section{CHOLINERGIC MODULATION OF RB CELL GABAERGIC INHIBITION}

In the mammalian retina, under photopic and scotopic conditions, ACh is released both tonically and in a light-induced manner (Masland and Livingstone, 1976; Massey and Neal, 1978, 1979a,b; Masland et al., 1984; O’Malley and Masland, 1993). Although currently the in vivo dynamics of ACh activation of A17 cells are unknown, our results support a system especially suited for sustained control of GABA release. Namely, nAChRs with sluggish kinetics gate slowly inactivating L-type VGCCs, inducing GABA release that binds preferentially high-affinity and slow $G_{A B A}$ receptors. Indeed, our data shows that the duration of nAChR-induced depolarization of A17 cells and GABA release onto $\mathrm{RB}$ cells was mainly controlled by $\mathrm{ACh}$ availability and AChE activity (Figure 6), demonstrating that ACh can control RB cell activity on a slow time scale. Moreover, the lack of nAChR-mediated synaptic events suggests that activation of A17 nicotinic receptors occurs extrasynaptically, a common mechanism for cholinergic neurotransmission in the CNS that enables long-lasting modulation of synaptic activity (Dani and Bertrand, 2007; Lawrence, 2008; Lendvai and Vizi, 2008; Arroyo et al., 2014). In the retina, fast synaptic nAChR activation could be expected for cells directly connected to SAC output (Brown and Masland, 1999; Yamada et al., 2003; Dong et al., 2004; Fried et al., 2005), but ACh also influences GCs that do not make synaptic contacts with SACs (Ames and Pollen, 1969; Masland and Ames, 1976; Ariel and Daw, 1982; Strang et al., 2003, 2005). This suggests that volume release of ACh is an important mode of cholinergic transmission in the retina, as it is for the dopaminergic (Puopolo et al., 2001), melatoninergic (Huang et al., 2013) and nitrergic systems (Vielma et al., 2012). On the other hand, injection of AChE inhibitors into the rat vitreous reduced the b-wave of the scotopic flash ERG response in the rat, probably due to an enhanced activation of nAChRs, as it could be partially replicated by injection of a specific agonist (Figure 7). This result is in agreement with 
the observed effects of nicotine in humans (Jurklies et al., 1996; Varghese et al., 2011) and shows that activity of bipolar cells is actively modulated by nAChRs in vivo, although the exact nature and dynamic properties of this modulation require further assessment.

\section{CONCLUSION}

We are still far from understanding the complexities of the retinal cholinergic neurotransmitter system as the functional relevance of the widespread expression of cholinergic receptors has been elusive, with the notable exceptions of ACh effects on directionselective GCs (Grzywacz et al., 1998; Fried et al., 2005; Reed et al., 2005) and during development (Feller, 2002). This study demonstrates that in the adult rat retina, $\mathrm{ACh}$ is a major player in the regulation of GABAergic inhibition of RB cells. We hypothesize that non-synaptic nAChR activation slowly depolarizes A17 cells, which facilitates GABA release via L-type VGCCs enhancing its gain control function of the RB-AII cell synapse (Dong and Hare, 2002a,b). This cholinergic control provides A17 cells with a modulatory system independent from the activity of RB cells, their main excitatory input and exclusive output, an advantageous situation that would greatly improve the adaptability and computational capabilities of A17 amacrine cells.

\section{AUTHOR CONTRIBUTIONS}

Claudio Elgueta designed, performed and analyzed the experiments, designed acquisition and analytical tools and wrote the paper. Oliver Schmachtenberg and Adrian G. Palacios designed the experiments and wrote the paper. Alex H. Vielma performed experiments and analyzed the data.

\section{ACKNOWLEDGMENTS}

This work was supported by FONDECYT 1120513 (Oliver Schmachtenberg), 1110292 (Adrian G. Palacios), 3140599 (Alex H. Vielma), the Millennium Institute ICM-P09-022 and a CONICYT Ph. D support grant (Claudio Elgueta). We thank Dr. Patricio Iturriaga for helpful discussions and the generous gift of some supplies. We also thank Dr. Andres Chávez and Dr. Michael Strüber for their helpful suggestions and comments in previous versions of the manuscript.

\section{SUPPLEMENTARY MATERIAL}

The Supplementary Material for this article can be found online at: http://www.frontiersin.org/journal/10.3389/fncel. 2015.00006/abstract

\section{REFERENCES}

Albuquerque, E. X., Pereira, E. F. R., Alkondon, M., and Rogers, S. W. (2009). Mammalian Nicotinic acetylcholine receptors: from structure to function. Physiol. Rev. 89, 73-120. doi: 10.1152/physrev.00015.2008

Alkondon, M., and Albuquerque, E. (1993). Diversity of nicotinic acetyicholine receptors in rat hippocampal neurons. I. pharmacological and functional evidence for distinct structural subtypes. J. Pharmacol. Exp. Ther. 265, 1455-1473.

Alkondon, M., and Pereira, E. (1999). Choline and selective antagonists identify two subtypes of nicotinic acetylcholine receptors that modulate GABA release from CA1 interneurons in rat hippocampal slices. J. Neurosci. 19, 2693-2705.

Ames, A., and Pollen, D. A. (1969). Neurotransmission in central nervous tissue: a study of isolated rabbit Retina. J. Neurophysiol. 32, 424-442.
Ariel, M., and Daw, N. W. (1982). Effects of cholinergic drugs on receptive field properties of rabbit retinal ganglion cells. J. Physiol. 324, 135-160. doi: 10.1113/jphysiol.1982.sp014104

Arroyo, S., Bennett, C., and Hestrin, S. (2014). Nicotinic modulation of cortical circuits. Front. Neural Circuits 8:30. doi: 10.3389/fncir.2014.00030

Bloomfield, S. A., and Dacheux, R. F. (2001). Rod vision: pathways and processing in the mammalian retina. Prog. Retin. Eye Res. 20, 351-384. doi: 10.1016/S13509462(00)00031-8

Briggman, K. L., Helmstaedter, M., and Denk, W. (2011). Wiring specificity in the direction-selectivity circuit of the retina. Nature 471, 183-188. doi: $10.1038 /$ nature 09818

Brown, S. P., and Masland, R. H. (1999). Costratification of a population of bipolar cells with the direction-selective circuitry of the rabbit retina. J. Comp. Neurol. $106,97-106$.

Chávez, A. E., and Diamond, J. S. (2008). Diverse mechanisms underlie glycinergic feedback transmission onto rod bipolar cells in rat retina. J. Neurosci. 28, 7919-7928. doi: 10.1523/JNEUROSCI.0784-08.2008

Chávez, A. E., Grimes, W. N., and Diamond, J. S. (2010). Mechanisms underlying lateral GABAergic feedback onto rod bipolar cells in rat retina. J. Neurosci. 30, 2330-2339. doi: 10.1523/JNEUROSCI.5574-09.2010

Chávez, A. E., Singer, J. H., and Diamond, J. S. (2006). Fast neurotransmitter release triggered by Ca influx through AMPA-type glutamate receptors. Nature 443, 705-708. doi: 10.1038/nature05123

Dajas-Bailador, F., and Wonnacott, S. (2004). Nicotinic acetylcholine receptors and the regulation of neuronal signalling. Trends Pharmacol. Sci. 25, 317-324. doi: 10.1016/j.tips.2004.04.006

Damaj, M. I., Wiley, J. L., Martin, B. R., and Papke, R. L. (2005). In vivo characterization of a novel inhibitor of CNS nicotinic receptors. Eur. J. Pharmacol. 521, 43-48. doi: 10.1016/j.ejphar.2005.06.056

Dani, J. A., and Bertrand, D. (2007). Nicotinic acetylcholine receptors and nicotinic cholinergic mechanisms of the central nervous system. Annu. Rev. Pharmacol. Toxicol. 47, 699-729. doi: 10.1146/annurev.pharmtox.47.120505.105214

Decker, M., and Anderson, D. (1995). Erysodine, a competitive antagonist at neuronal nicotinic acetylcholine receptors. Eur. J. Pharmacol. 280, 79-89. doi: 10.1016/0014-2999(95)00191-M

Dmitrieva, N., MacNeil, M. A., Wang, F., Masland, R. H., Lindstrom, J. M., and Keyser, K. T. (2003). Identification of cholinoceptive glycinergic neurons in the mammalian retina. J. Comp. Neurol. 456, 167-175. doi: 10.1002/cne.10520

Dmitrieva, N. A., Strang, C. E., and Keyser, K. T. (2007). Expression of Alpha 7 nicotinic acetylcholine receptors by bipolar, amacrine, and ganglion cells of the rabbit retina. J. Histochem. Cytochem. 55, 461-476. doi: 10.1369/jhc.6A7116.2006

Dmitrieva, N. A., Lindstrom, J. M., and Keyser, K. T. (2001). The relationship between GABA-containing cells and the cholinergic circuitry in the rabbit retina. Vis. Neurosci. 18, 93-100. doi: 10.1017/S0952523801181083

Dong, C., and Hare, W. (2002a). GABAc feedback pathway modulates the amplitude and kinetics of ERG b-wave in a mammalian retina in vivo. Vision Res. 42, 1081-1087. doi: 10.1016/S0042-6989(02)00032-9

Dong, C.-J., and Hare, W. A. (2002b). Temporal modulation of scotopic visual signals by A17 amacrine cells in mammalian retina in vivo. J. Neurophysiol. 89, 2159-2166. doi: 10.1152/jn.01008.2002

Dong, W., Sun, W., Zhang, Y., Chen, X., and He, S. (2004). Dendritic relationship between starburst amacrine cells and direction-selective ganglion cells in the rabbit retina. J. Physiol. 556, 11-17. doi: 10.1113/jphysiol.2004.060715

Eggers, E. D., and Lukasiewicz, P. D. (2006). GABA(A), GABA(C) and glycine receptor-mediated inhibition differentially affects light-evoked signalling from mouse retinal rod bipolar cells. J. Physiol. 572, 215-225. doi: 10.1113/jphysiol.2005.103648

Eggers, E. D., McCall, M. A., and Lukasiewicz, P. D. (2007). Presynaptic inhibition differentially shapes transmission in distinct circuits in the mouse retina. J. Neurosci. 582, 569-582. doi: 10.1113/jphysiol.2007.131763

Feller, M. B. (2002). The role of nAChR-Mediated spontaneous retinal activity in visual system development. J. Neurobiol. 53, 556-567. doi: 10.1002/neu.10140

Fletcher, E. L., Koulen, P., and Wa, H. (1998). GABAA and GABAC receptors on mammalian rod bipolar cells. J. Comp. Neurol. 365, 351-365.

Fried, S. I., Münch, T. A., and Werblin, F. S. (2005). Directional selectivity is formed at multiple levels by laterally offset inhibition in the rabbit retina. Neuron 46, 117-127. doi: 10.1016/j.neuron.2005.02.007

Fucile, S. (2004). Ca2+ permeability of nicotinic acetylcholine receptors. Cell Calcium 35, 1-8. doi: 10.1016/j.ceca.2003.08.006 
Grimes, W. N., Li, W., Chávez, A. E., and Diamond, J. S. (2009). BK channels modulate pre- and postsynaptic signaling at reciprocal synapses in retina. Nat. Neurosci. 12, 585-592. doi: 10.1038/nn.2302

Grzywacz, N. M., Merwine, D. K., and Amthor, F. R. (1998). Complementary roles of two excitatory pathways in retinal directional selectivity. Vis. Neurosci. 15, 1119-1127. doi: 10.1017/S0952523898156109

Hartveit, E. (1999). Reciprocal synaptic interactions between rod bipolar cells and amacrine Cells in the rat retina. J. Neurophysiol. 81, 2923-2936.

Harvey, S. C., and Luetje, C. W. (1996). Determinants of competitive antagonist sensitivity on neuronal nicotinic Receptor $\beta$ subunits. J. Neurosci. 16, 3798-3806.

Harvey, S. C., Maddox, F. N., and Luetje, C. W. (1996). Determinants of Dihydro$\beta$-Erythroidine sensitivity on rat neuronal nicotinic receptor $\alpha$ subunits. J. Neurochem. 67, 1953-1959. doi: 10.1046/j.1471-4159.1996.67051953.x

Huang, H., Wang, Z., Weng, S.-J., Sun, X.-H., and Yang, X.-L. (2013). Neuromodulatory role of melatonin in retinal information processing. Prog. Retin. Eye Res. 32, 64-87. doi: 10.1016/j.preteyeres.2012.07.003

Iturriaga-Vásquez, P., Carbone, A., García-Beltrán, O., Livingstone, P. D., Biggin, P. C., Cassels, B. K., et al. (2010). Molecular determinants for competitive inhibition of alpha $\alpha 4 \beta 2$ nicotinic acetylcholine receptors. Mol. Pharmacol. 78 , 366-375. doi: 10.1124/mol.110.065490

Jurklies, B., Kaelin-Lang, A., and Niemeyer, G. (1996). Cholinergic effects on cat retina in vitro: changes in rod- and cone-driven b-wave and optic nerve response. Vision Res. 36, 797-816. doi: 10.1016/0042-6989(95) 00172-7

Keyser, K. T., MacNeil, M. A., Dmitrieva, N., Wang, F., Masland, R. H., and Lindstrom, J. M. (2000). Amacrine, ganglion, and displaced amacrine cells in the rabbit retina express nicotinic acetylcholine receptors. Vis. Neurosci. 17, 743-752. doi: 10.1017/S095252380017508X

Kim, I., Lee, M., Oh, S., Kim, K., and Chun, M. (1998). Double-labeling techniques demonstrate that rod bipolar cells are under GABAergic control in the inner plexiform layer of the rat retina. Cell Tissue Res. 292, 17-25. doi: 10.1007/s004410051030

Kittila, C. A., and Massey, S. C. (1997). Pharmacology of directionally selective ganglion cells in the rabbit retina. J. Neurophysiol. 77, 675-689.

Koulen, P., Brandstätter, J. H., Enz, R., Bormann, J., and Wässle, H. (1998). Synaptic clustering of GABA(C) receptor $\rho$-subunits in the rat retina. Eur. J. Neurosci. 10, 115-127. doi: 10.1046/j.1460-9568.1998.00005.x

Lawrence, J. J. (2008). Cholinergic control of GABA release: emerging parallels between neocortex and hippocampus. Trends Neurosci. 31, 317-327. doi: 10.1016/j.tins.2008.03.008

Lendvai, B., and Vizi, E. S. (2008). Nonsynaptic chemical transmission through nicotinic acetylcholine receptors. Physiol. Rev. 88, 333-349. doi: 10.1152/physrev.00040.2006

Luetje, C., and Patrick, J. (1991). Both $\alpha$ - and $\beta$-subunits contribute to the agonist sensitivity of neuronal nicotinic acetylcholine receptors. J. Neurosci. 17, 837-845.

Macneil, M. A., and Masland, R. H. (1998). Extreme diversity among amacrine cells: implications for function. Neuron 20, 971-982. doi: 10.1016/S08966273(00)80478-X

Mansvelder, H. D., van Aerde, K. I., Couey, J. J., and Brussaard, A. B. (2006). Nicotinic modulation of neuronal networks: from receptors to cognition. Psychopharmacology (Berl.) 184, 292-305. doi: 10.1007/s00213-005-0070-Z

Marc, R. (2004). "Retinal neurotransmitters," in The Visual Neurosciences, eds J. Werner and L. Chalupa (Cambridge, MA: MIT Press), 315-330.

Marritt, A. M., Cox, B. C., Yasuda, R. P., Mcintosh, J. M., Xiao, Y., Wolfe, B. B., et al. (2005). Nicotinic cholinergic receptors in the rat retina: simple and mixed heteromeric subtypes. Mol. Pharmacol. 68, 1656-1668. doi: 10.1124/mol.105.012369

Masland, R. (2012). The neuronal organization of the retina. Neuron 76, 266-280. doi: 10.1016/j.neuron.2012.10.002

Masland, R. H., and Ames, A. (1976). Responses to acetylcholine of ganglion cells in an isolated mammalian retina. J. Neurophysiol. 39, 1220-1235.

Masland, R. H., and Livingstone, C. J. (1976). Effect of stimulation with light on synthesis and release of acetylcholine by an isolated mammalian retina. J. Neurophysiol. 39, 1210-1219.

Masland, R. H., Mills, J. W., and Cassidy, C. (1984). The functions of acetylcholine in the rabbit retina. Proc. R. Soc. Lond. B. Biol. Sci. 223, 121-139. doi: 10.1098/rspb.1984.0086
Massey, S. C., and Neal, M. J. (1978). Light evoked release of acetylcholine from the rabbit retina in vivo [proceedings]. J. Physiol. 280, 51P-52P.

Massey, S. C., and Neal, M. J. (1979a). Release of [3H]-acetylcholine from the isolated retina of the rat by potassium depolarization: dependence on high affinity choline uptake. Br. J. Pharmacol. 65, 271-276.

Massey, S. C., and Neal, M. J. (1979b). The light evoked release of acetylcholine from the rabbit retina in vivo and its inhibition by gamma-aminobutyric acid. J. Neurochem. 32, 1327-1329. doi: 10.1111/j.1471-4159.1979.tb11062.x

Menger, N., and Wässle, H. (2000). Morphological and physiological properties of the A17 amacrine cell of the rat retina. Vis. Neurosci. 17, 769-780.

Millar, N. S., and Gotti, C. (2009). Diversity of vertebrate nicotinic acetylcholine receptors. Neuropharmacology 56, 237-246. doi: 10.1016/j.neuropharm.2008.07.041

Moretti, M., Vailati, S., Zoli, M., Lippi, G., Riganti, L., Longhi, R., et al. (2004). Nicotinic acetylcholine receptor subtypes expression during rat retina development and their regulation by visual experience. Mol. Pharmacol. 66, 85-96. doi: 10.1124/mol.66.1.85

Moyano, M., Porteros, A., and Dowling, J. E. (2013). The effects of nicotine on cone and rod b-wave responses in larval zebrafish. Vis. Neurosci. 30, 141-145. doi: 10.1017/S0952523813000187

Nakatsuka, K., and Hamasaki, D. (1985). Destruction of the indoleomine-accumulating amacrine cells alters the ERG of rabbits. Invest. Ophthalmol. Vis. Sci. 26, 1109-1116.

O’Malley, D. M., and Masland, R. H. (1993). Responses of the starburst amacrine cells to moving stimuli. J. Neurophysiol. 69, 730-738.

Papke, R., Buhr, J., and Francis, M. (2005). The effects of subunit composition on the inhibition of nicotinic receptors by the amphipathic blocker 2,2,6,6Tetramethylpiperidin-4-yl Heptanoate. Mol. Pharmacol. 67, 1977-1990. doi: 10.1124/mol.105.011676

Papke, R. L., and Heinemann, S. F. (1993). Partial agonist properties of cytisine on neuronal nicotinic receptors containing the $\beta 2$ subunit. Mol. Pharmacol. 45, 142-149.

Papke, R. L., and Heinemann, S. F. (1994). The role of the $\beta 4$-subunit in determining the kinetic properties of rat neuronal nicotinic acetylcholine $\alpha 3$-receptors. J. Physiol. 440, 95-112. doi: 10.1113/jphysiol.1991.sp018698

Papke, R. L., Webster, J. C., Lippiello, P. M., Bencherif, M., and Francis, M. M. (2000). The activation and inhibition of human nicotinic acetylcholine receptor by RJR-2403 indicate a selectivity for the $\alpha 4 \beta 2$ receptor subtype. J. Neurochem. 75, 204-216. doi: 10.1046/j.1471-4159.2000.0750204.x

Protti, D., and Llano, I. (1998). Calcium currents and calcium signaling in rod bipolar cells of rat retinal slices. J. Neurosci. 18, 3715-3724.

Puopolo, M., Hochstetler, S. E., Gustincich, S., Wightman, R. M., Raviola, E., Hill, C., et al. (2001). Extrasynaptic release of dopamine in a retinal neuron: activity dependence and transmitter modulation. Neuron 30, 211-225. doi: 10.1016/S0896-6273(01)00274-4

Quick, M. W., Ceballos, R. M., Kasten, M., Mcintosh, J. M., and Lester, R. A. J. (1999). $\alpha 3 \beta 4$ subunit-containing nicotinic receptors dominate function in rat medial habenula neurons. Neuropharmacology 38, 769-783. doi: 10.1016/S0028-3908(99)00024-6

Reed, B. T., Keyser, K. T., and Amthor, F. R. (2005). MLA-sensitive cholinergic receptors involved in the detection of complex moving stimuli in retina. Vis. Neurosci. 21, 861-872. doi: 10.1017/S0952523804216066

Schmidt, M., Humphrey, M. F., and Wässle, H. (1987). Action and localization of acetylcholine in the cat retina. J. Neurophysiol. 58, 997-1015.

Singer, J. H., and Diamond, J. S. (2003). Sustained Ca2+ entry elicits transient postsynaptic currents at a retinal ribbon synapse. J. Neurosci. 23, 10923-10933.

Smith, D. V., and Uteshev, V. V. (2008). Heterogeneity of nicotinic acetylcholine receptor expression in the caudal nucleus of the solitary tract. Neuropharmacology 54, 445-453. doi: 10.1016/j.neuropharm.2007.10.018

Strang, C. E., Amthor, F. R., and Keyser, K. T. (2003). Rabbit retinal ganglion cell responses to nicotine can be mediated by $\beta 2$-containing nicotinic acetylcholine receptors. Vis. Neurosci. 20, 651-662. doi: 10.1017/S0952523803206076

Strang, C. E., Andison, M. E., Amthor, F. R., and Keyser, K. T. (2005). Rabbit retinal ganglion cells express functional $\alpha 7$ nicotinic acetylcholine receptors. Am. J. Physiol. Cell Physiol. 289, C644-C655. doi: 10.1152/ajpcell.00633. 2004

Strang, C. E., Renna, J. M., Amthor, F. R., and Keyser, K. T. (2007). Nicotinic acetylcholine receptor expression by directionally selective ganglion cells. Vis. Neurosci. 24, 523-533. doi: 10.1017/S0952523807070435 
Strang, C. E., Renna, J. M., Amthor, F. R., and Keyser, K. T. (2010). Muscarinic acetylcholine receptor localization and activation effects on ganglion response properties. Invest. Ophthalmol. Vis. Sci. 51, 2778-2789. doi: 10.1167/iovs. 09-4771

Strettoi, E., Dacheux, R., and Raviola, E. (1990). Synaptic connections of rod bipolar cells in the inner plexiform layer of the rabbit retina. J. Comp. Neurol. 466, 449-466. doi: 10.1002/cne.902950309

Takeda, D., Nakatsuka, T., Papke, R., and Gu, J. (2003). Modulation of inhibitory synaptic activity by a non- $\alpha 4 \beta 2$, non- $\alpha 7$ subtype of nicotinic receptors in the substantia gelatinosa of adult rat spinal cord. Pain 101, 13-23. doi: 10.1016/S0304-3959(02)00074-X

Varghese, S. B., Reid, J. C., Hartmann, E. E., and Keyser, K. T. (2011). The effects of nicotine on the human electroretinogram. Invest. Ophthalmol. Vis. Sci. 52, 9445-9451. doi: 10.1167/iovs.11-7874

Vielma, A., Delgado, L., Elgueta, C., Osorio, R., Palacios, A. G., and Schmachtenberg, O. (2010). Nitric oxide amplifies the rat electroretinogram. Exp. Eye Res. 91, 700-9. doi: 10.1016/j.exer.2010.08.014

Vielma, A. H., Retamal, M. A., and Schmachtenberg, O. (2012). Nitric oxide signaling in the retina: what have we learned in two decades? Brain Res. 1430, 112-125. doi: 10.1016/j.brainres.2011.10.045

Vizi, E. S., and Lendvai, B. (1999). Modulatory role of presynaptic nicotinic receptors in synaptic and non-synaptic chemical communication in the central nervous system. Brain Res. Rev. 30, 219-235. doi: 10.1016/S0165-0173(99) 00016-8

Voigt, T. (1986). Cholinergic amacrine cells in the rat retina. J. Comp. Neurol. 248, 19-35. doi: 10.1002/cne.902480103

Wassélius, J., Johansson, K., Bruun, A., Zucker, C., and Ehinger, B. (1998). Correlations between cholinergic neurons and muscarinic $\mathrm{m} 2$ receptors in the rat retina. Neuroreport 9, 1799-1802. doi: 10.1097/00001756-199806010-00023
Wässle, H. (2004). Parallel processing in the mammalian retina. Nat. Rev. Neurosci. 5, 747-757. doi: 10.1038/nrn1497

Weymouth, A. E., and Vingrys, A. J. (2008). Rodent electroretinography: methods for extraction and interpretation of rod and cone responses. Prog. Retin. Eye Res. 27, 1-44. doi: 10.1016/j.preteyeres.2007.09.003

Witkovsky, P. (2004). Dopamine and retinal function. Doc. Ophthalmol. 108, 17-40. doi: 10.1023/B:DOOP.0000019487.88486.0a

Yamada, E. S., Dmitrieva, N., Keyser, K. T., Lindstrom, J. M., Hersh, L. B., and Marshak, D. W. (2003). Synaptic connections of starburst amacrine cells and localization of acetylcholine receptors in primate retinas. J. Comp. Neurol. 461, 76-90. doi: 10.1002/cne.10672

Conflict of Interest Statement: The authors declare that the research was conducted in the absence of any commercial or financial relationships that could be construed as a potential conflict of interest.

Received: 19 October 2014; accepted: 07 January 2015; published online: 09 February 2015.

Citation: Elgueta C, Vielma AH, Palacios AG and Schmachtenberg O (2015) Acetylcholine induces GABA release onto rod bipolar cells through heteromeric nicotinic receptors expressed in A17 amacrine cells. Front. Cell. Neurosci. 9:6. doi: 10.3389/ fncel.2015.00006

This article was submitted to the journal Frontiers in Cellular Neuroscience.

Copyright (c) 2015 Elgueta, Vielma, Palacios and Schmachtenberg. This is an openaccess article distributed under the terms of the Creative Commons Attribution License (CC BY). The use, distribution or reproduction in other forums is permitted, provided the original author(s) or licensor are credited and that the original publication in this journal is cited, in accordance with accepted academic practice. No use, distribution or reproduction is permitted which does not comply with these terms. 